Teresa Sacchet

Universidade de São Paulo

\title{
Representação política, representação de grupos e política de cotas: perspectivas e contendas feministas
}

\begin{abstract}
Resumo: Este artigo foca no debate sobre representação política, representação especial de grupos e política de cotas com o objetivo de destacar os seus argumentos principais e mais controversos, explorando suas inconsistências, problematizando-os e estabelecendo um diálogo entre eles. Será considerado até que ponto o argumento por maior inclusão de membros de grupos sociais não hegemônicos em processos político-decisórios, através de mecanismos como as cotas, pode ser justificado desde uma perspectiva normativa. Dado o caráter polêmico do conceito de representação política e da noção de identidades e interesses de grupos, em que se justificaria essa demanda? Esta discussão será conduzida a partir de uma análise sobre o conceito de representação política, da noção de interesses, identidades e perspectivas de grupos, e de uma análise sobre os principais argumentos apresentados a favor das cotas e contra elas. O artigo foca na representação política das mulheres, estabelecendo assim um diálogo permanente com e entre perspectivas feministas.
\end{abstract}

Palavras-chave: representação política; representação de grupos; cotas; democracia; mulheres; gênero.

Copyright (c) 2012 by Revista Estudos Feministas.

\section{Introdução}

A exclusão de grupos sociais de processos políticodecisórios é tópico corrente em discussões acadêmicas sobre democracia, justiça, igualdade política e representatividade das políticas públicas. O argumento pela representação especial de grupos estruturalmente desfavorecidos é articulado através de perspectivas que sustentam a existência de uma relação estreita entre democracia e inclusão política; que afirmam que a justiça implica o reconhecimento das diferenças através da participação ativa de membros desses grupos em processos político-decisórios; que julgam o conceito liberal de 
1 Jurgen HABERMAS, 1976; Charles TAYLOR, 1994; e Alain TOURAINE, 1981.

2 Jane MANSBRIDGE, 1999; e Anne PHILLIPS, 1995 e 1999. igualdade política como deficitário na medida em que não incorpora requisitos objetivos necessários para que homens e mulheres disputem processos eleitorais em condições de igualdade; e, por fim, que defendem haver uma relação estreita entre quem é o legislador e o conteúdo do que é legislado. Para além de variáveis institucionais, comumente utilizadas na ciência política para medir níveis de desenvolvimento democrático como voto universal, eleições livres e diretas, e do império da lei, a democracia é entendida aqui como sendo também uma questão de grau de envolvimento e de participação social na vida política da nação. A democratização seria, assim, mais que a extensão dos requisitos institucionais supramencionados. Ela efetivarse-ia também, e particularmente, pela inclusão progressiva de diferentes grupos sociais no processo de tomada de decisão política.

A desconfiança das instituições democráticas vivenciada por grande parte dos países ocidentais e manifesta nos baixos índices de participação eleitoral e no desinteresse político é, dentre outros fatores, expressão de um distanciamento dos representantes de vastos setores da população. Há constante manifestação de descontentamento e descrédito dos cidadãos dos seus representantes e um sentimento de desconexão e impotência para influenciar os processos políticos. Por consequência, em países como o Brasil, onde há obrigatoriedade do voto, esse é por vezes visto como um instrumento de legitimação de um jogo de cartas marcadas. A implementação de medidas que favoreçam a participação de membros de diferentes grupos em processos democráticos é, assim, também proposta como um meio de aumentar a confiança dos cidadãos em suas instituições públicas e aproximá-los delas, favorecendo a participação e o engajamento político.

Os projetos sugeridos para alterar o quadro de concentração de poder político partem de diferentes interpretações teóricas, mas comum a várias delas é a percepção de que o modelo de democracia parlamentar, conforme articulado presentemente, é deficitário no que concerne à inclusão de ideias, interesses e perspectivas de setores sociais mais amplos. Dois projetos ganham destaque neste debate: um deles visa ao aprofundamento da democracia, através de modelos participativos implementados em nível da sociedade civil;' o outro advoga uma maior participação de grupos sociais em processos de tomada de decisão das instituições políticas, por meio de políticas de ações afirmativas e de cotas. ${ }^{2}$ Essas posições não são dicotômicas, e muitos dos adeptos da segunda são também defensores da primeira, e vice-versa. Mas, enquanto no primeiro caso, o foco está em processos 
societários e o objetivo é o de alavancar mudanças tanto no plano material quanto no cultural, no segundo, a participação em esferas representativas oficiais é vista como um meio essencial de promoção da igualdade e de construção da justiça social. Nesta última interpretação, uma das grandes debilidades da democracia parlamentar é identificada exatamente no seu caráter excludente, que limita processos políicos a visões de elites sociais com traços semelhantes de classe, gênero e raça. É nessa perspectiva que este artigo será enfocado.

Para além do debate acadêmico, a inclusão de grupos sociais em processos políticos institucionais passou a ser recomendada por organismos multilaterais e por governos, e é demanda corrente entre atores no espaço da sociedade civil, que veem nela um meio de reconhecer as diferenças existentes entre os cidadãos, bem como de tornar processos políticos mais representativos. O projeto não é pela mera extensão de direitos a setores civis marginalizados, mas por sua integração na própria definição da agenda política. Com a extensão dos direitos formais de cidadania, a atenção volta-se agora para o aspecto substantivo da democracia, e uma das suas questões centrais diz respeito à participação de diferentes grupos em processos políticodecisórios.

Mas a inclusão de grupos sociais em espaços de tomada de decisão política, assim como os instrumentos propostos para atingir tal objetivo - em particular as cotas como uma das principais medidas postuladas - são assuntos controversos. Dentre as questões levantadas duas merecem destaque: a primeira refere-se à noção de representação política. O que ou quem os representantes políticos efetivamente representam nas esferas políticas deliberativas não é evidente. Embora se entenda que o papel do representante seja o de defender perspectivas e interesses, há controvérsias sobre a quem esses diriam respeito. Quem os representantes representam? Os projetos de seus partidos? A nação? Os grupos aos quais pertencem? As suas próprias ideias e interesses? A impossibilidade de definir objetivamente o que significa representação política parece tornar sem sentido a demanda por uma maior presença de grupos discriminados em esferas legislativas como meio de aumentar a accountability desses espaços. Afinal, a quem os representantes deveriam prestar contas?

Em segundo lugar, a proposta de inclusão política de grupos como um meio democratizante de processos políticodecisórios que os tornaria mais expressivos das visões e dos interesses de vastos setores sociais também é contestada por razões similares. A noção de que membros de grupos sociais discriminados seriam melhores articuladores e defensores dos 
interesses do seu grupo é acusada de ser essencializante, na medida em que grupos sociais de composição plural seriam assim tomados como categorias homogêneas. Os membros daqueles que são externamente definidos como grupos sociais discriminados ou explorados têm vivências, valores e interesses diversos, os quais são constantemente alterados tanto pelas suas experiências de vidas quanto por suas ações particulares e coletivas. As mulheres, por exemplo, são de diferentes classes sociais, raças, etnias, idades, nacionalidades, religiões etc., e, portanto, possuem múltiplas experiências, interesses, identidades, valores e interpretações distintas sobre esses. Assim, o argumento é de que não há nada que garanta que pessoas com traços físicos e experiências pessoais semelhantes tenham visões similares sobre seus interesses ou se reconheçam como portadoras de identidades comuns. Mesmo em situação de relativa identidade entre representantes e representados, a representação de interesses seria impossibilitada pela ausência de interesses objetivos. Dentro dessa interpretação, a demanda pela inclusão de grupos em processos políticos democráticos com base no argumento da representatividade também não faria sentido.

Logo, o tópico da representação especial de grupos é polêmico e revela questões importantes do debate sobre democracia e representação política. A intenção deste artigo é focar este debate a partir de diferentes perspectivas analisando questões pertinentes a elas, como, por exemplo, dado o caráter controverso do conceito de representação e a impossibilidade de se objetivarem os interesses, em que se sustentaria a demanda por representação especial de grupos? Quais mecanismos poderiam facilitar a inclusão de perspectivas e interesses de grupos em processos políticodecisórios? Seriam esses instrumentos legítimos desde um ponto de vista normativo? O artigo irá focar tais questões a partir da demanda por um aumento na presença de mulheres em processos político-decisórios. Será estabelecido um diálogo constante entre diferentes perspectivas feministas, por sua contribuição destacada neste debate.

Vale notar que o texto se utiliza de várias citações de autores de língua inglesa. Para favorecer a compreensão do leitor e a fluência do texto, optei por traduzi-las. Todas as traduções do texto foram efetuadas por mim.

\section{Interpretações feministas sobre a exclusão política das mulheres e suas estratégias}

A crítica feminista sobre a exclusão política das mulheres incorpora análises de períodos e contextos distintos 
${ }^{3}$ Carole PATEMAN, 1989, p. 14.

${ }^{4}$ PATEMAN, 1988. para explicitar tanto as formas como as mulheres foram historicamente excluídas da política formal como as suas consequências. Um dos principais alvos é a construção do Estado moderno e sua ordem político-jurídica, que teriam sido fundados no princípio da separação entre a esfera pública e a esfera privada e em valores ditos masculinos. Em seu livro The Sexual Contract, Carole Pateman analisa o debate de Locke com os patriarcalistas sobre autoridade política e autoridade patriarcal para argumentar de forma pertinente que o Estado moderno e suas instituições teriam sido idealizados e estruturados a partir da separação da esfera pública da esfera privada. Segundo essa autora, a noção de cidadania, como conceito relacionado à esfera pública e às relações dos indivíduos com Estado, "foi construída na imagem masculina" e, por conseguinte, a inclusão política das mulheres na atualidade constitui-se em tarefa difícil e efetua-se de forma diferente da inclusão original dos homens. ${ }^{3} \mathrm{O}$ projeto liberal por direitos universais e abstratos dos indivíduos teria sido espelhado na imagem e na experiência dos homens e, assim, direitos relacionados ao universo feminino, como, por exemplo, o direito reprodutivo, ficariam deslocados da agenda pública, por serem diferentes de qualquer direito tradicionalmente reconhecido e assegurado ao indivíduo masculino. ${ }^{4}$

O conceito de indivíduo autônomo e autointeressado pressuposto nessa perspectiva, segundo alguns autores feministas, exclui as experiências e as relações de interdependência que se estabelecem no âmbito da vida mais íntima da família e da comunidade e, consequentemente, as mulheres. Pateman acredita que muitas diferenças são socialmente construídas através da educação diferenciada de meninos e meninas, mas que há diferenças biológicas que são perenes e que a cidadania das mulheres implicaria repensar o estado a partir dessas diferenças. Para Pateman, a construção de um projeto político igualitário implicaria uma reestruturação do modelo atual, em que a esfera pública e a privada fossem reorganizadas levando em conta as diferenças entre homens e mulheres.

Apesar de ser uma forma específica de leitura social, a perspectiva liberal é apresentada como neutra e universal. Há entre as feministas uma denúncia do caráter excludente das normas políticas liberais, que, embora se proponham neutras, são fundadas em padrões culturais específicos que favorecem alguns grupos sobre outros. Grupos sociais específicos têm dominado a definição da agenda política, definindo os termos da discussão e ditando a conduta dessas esferas. Phillips argumenta que as normas que governam os comportamentos das instituições políticas definem limites claros entre a esfera pública e a privada e, 
${ }^{5}$ PHILLIPS, 1999, p. 24.

${ }^{6}$ PHILLIPS, 1999, p. 24.

${ }^{7}$ Ruth LISTER, 1990 e 1997; Ursula VOGEL, 1991; e Sylvia WALBY, 1994. assim, "aqueles que desobedecerem estes limites (levando seus bebês para reuniões políticas, deixando suas emoções 'intervirem' nos debates racionais) serão considerados disruptivos, peculiares, e mal adaptados aos padrões da vida democrática", ${ }^{5}$ ou seja, embora as regras de comportamento político sejam consideradas neutras, "como as características sociais são fundadas em diferenças de gênero, o que passa como neutralidade resulta como sendo tratamento preferencial para os homens". 6

Para um grande número de autores feministas, a noção de direitos universais de cidadania pressuposta no modelo político atual não se refere a todos indiscriminadamente, na medida em que é limitada no que diz respeito a incorporar as experiências "particulares" das mulheres e de outros grupos não hegemônicos, sendo, consequentemente, deficitária para atender as suas necessidades e interesses. ${ }^{7}$ Nesse modelo, tanto o objeto da política como os seus agentes encontrar-se-iam localizados nas esferas públicas, e a esfera privada, por sua vez, um dos espaços centrais de exploração, risco e opressão das mulheres, seria excluída da política e das leis, e identificada como a esfera da intimidade, da recomposição e do desenvolvimento autônomo do indivíduo.

Na perspectiva liberal priorizar os direitos gerais e abstratos dos indivíduos sobre os direitos particulares e concretos seria um meio de garantir a neutralidade e a objetividade de processos políticos. Direitos universais são considerados mais democráticos na medida em que eles visam atender indiscriminadamente às necessidades e aos interesses de "todos os cidadãos", sem distinção de classe, sexo, raça ou qualquer outra característica particular do indivíduo. Com base nisso, os governos promoveriam políticas para atender aos direitos comuns, tratando os cidadãos igualmente, e com isso seria esperado que os interesses de todos fossem igualmente contemplados. Mas, dado que a igualdade formal não implica automaticamente igualdade de fato e que há desequilíbrio de poder entre os cidadãos, se as demandas relacionadas a grupos sociais específicos forem negligenciadas, os direitos considerados universais podem consistir em expressão de tratamento privilegiado para membros de grupos raciais, de gênero e econômicos hegemônicos. Ainda que seja importante que não se percam de vista os aspectos comuns existentes entre as pessoas e que não se abandone a visão de igual valor intrínseco dos seres humanos que sustenta a noção de respeito entre membros de diferentes grupos e ajuda a combater preconceitos, as diferenças sociais devem ser levadas em conta para que sejam efetivados os princípios de justiça e igualdade. 
${ }^{8}$ PATEMAN, 1988.

9 Susan Moller OKIN, 1991; e PHILLIPS, 1995.

10 PHILLIPS, 1993, p. 12.

11 Iris Marion YOUNG, 1985.
Houve, sem dúvida, mudanças no modelo de organização do estado liberal. Através de pressões do movimento de mulheres e de ações legislativas, as instituições públicas ocidentais passaram a incorporar demandas relativas à esfera privada. A implementação de leis e mecanismos públicos de proteção às mulheres e crianças vítimas de violências perpetradas no âmbito da esfera doméstica é paradigmática dessa mudança. Apesar do movimento constante por mudanças, as instituições não são neutras no que tangem a valores e perspectivas de gênero, e é sobre tais estruturas que são edificadas as relações desiguais entre homens e mulheres.

O projeto feminista para se contrapor o modelo universalista de cidadania envolve tanto a sugestão pela reposição desse modelo por outro particularista quanto por seu aperfeiçoamento. Alguns autores argumentam que a construção de práticas igualitárias implica repensar a relação entre natureza e convenção, bem como entre a esfera doméstica e a esfera pública. A solução para a inclusão política das mulheres viria da afirmação das diferenças sexuais, em vez de sua negação em nome de um suposto indivíduo sem sexo. ${ }^{8}$ Para resolver o problema de um universalismo, digamos particularista, de forma a atender às diferenças biológicas e sociais existentes entre os indivíduos, o conceito de cidadania teria que incorporar as especificidades da condição de vida de homens e mulheres. A inclusão das mulheres como cidadãs na estrutura atual implicaria a desorganização desse modelo e a construção de um modelo alternativo.

Em contraponto, alguns autores acreditam que o modelo atual pode ser reparado a partir da inclusão de homens e mulheres como participantes iguais tanto na esfera pública quanto na privada. ${ }^{9} \mathrm{O}$ universalismo e o particularismo não são tomados como projetos antagônicos. Uma separação rígida entre universalismo e particularismo incentiva a fixação das diferenças, que constrói estereótipos sobre grupos sociais, dificultando comparações e construções de alianças necessárias para o estabelecimento de solidariedades entre eles. ${ }^{10} \mathrm{O}$ projeto pela equidade de gênero pressupõe destacar as diferenças e as desigualdades entre mulheres e homens, e entre as próprias mulheres, sem que haja necessidade de fixação de uma identidade feminina.

Teorias políticas liberais tendem a considerar a questão da definição da justiça como mera abstração de direitos $e$, consequentemente, sem necessidade de participação de diferentes grupos sociais na sua definição. Para Iris Marion Young, ${ }^{11}$ a definição da justiça sem a participação de grupos sociais distorce visões sobre seus 
12 YOUNG, 1985.

${ }^{13}$ Chantal MOUFFE, 1993 e 1999.

14 Ernesto LACLAU e Chantal MOUFFE, 2001. interesses, ao mesmo tempo que apresenta uma noção idealizada deles. A autora defende o que chama de feminismo gynocentric (ou feminismo da diferença), que pressupõe que a igualdade política signifique igualdade de acesso e de influência e implique igualdade de direitos civis, políticos e sociais, mas também tratamento especial para grupos que necessitam de direitos especiais. Young propõe suplantar o modelo de representação política contemporâneo, que ela chama de assimilacionista, com um projeto alternativo de representação especial de grupo no qual grupos sociais oprimidos teriam seus espaços próprios de articulação política (financiados pelo Estado), os quais seriam consultados e teriam poder de veto sobre projetos que dissessem respeito aos seus interesses. ${ }^{12}$

Alguns autores contestam o projeto de organização autônoma de grupos, pelo seu teor essencialista e separatista. A pós-estruturalista Chantal Mouffe ${ }^{13}$ se opõe à visão de Young argumentando que a construção de um espaço público diferenciado por sexo, ou por qualquer outra diferença de grupo, necessariamente envolveria a essencialização e a fixação de identidades de grupos que têm múltiplos pertencimentos. Toda identidade só adquire significado a partir de sua inserção em determinada configuração, num estado relacional com outras identidades. Assim, interesses e identidades teriam uma natureza instável, pois cada novo posicionamento do sujeito na estrutura social potencializaria a desestabilização e a construção de novos interesses e identidades. Portanto, nenhuma identidade teria um status especial que poderia dar sentido às demais. ${ }^{14} \mathrm{O}$ ideal de um público democrático inclusivo seria, por conseguinte, inatingível na medida em que a constituição de tal espaço automaticamente implicaria a exclusão de algumas identidades e de alguns interesses.

A democracia para Mouffe é construída através de antagonismos, divisões e conflitos entre grupos de interesses e identitários que lutam por direitos, e a sua tarefa deveria ser tornar inimigos em adversários através de instituições e práticas políticas. O objetivo da democracia não seria atingir consenso, como no ideal deliberacionista - já que a política é sempre imbricada em relações de poder e de conflito -, mas a constituição de espaços públicos verdadeiramente pluralistas, em que diferentes discursos buscassem legitimação e todos eles fossem reconhecidos como igualmente válidos. No ideal de democracia radical defendido pela autora, pluralismo e antagonismo são aspectos centrais, e o processo político pressupõe competição entre adversários e se efetiva no movimento por legitimação discursiva. A política é aqui, na sua própria essência, essa busca pela hegemonia discursiva e se efetua 
${ }^{15}$ PHILLIPS, 1993.

${ }^{16}$ PHILLIPS, 1993, p. 14.

17 PHILLIPS, 1999.

18 YOUNG, 2000, p. 137.

19 YOUNG, 2000, p. 136.

${ }^{20}$ YOUNG, 2000, p. 137. através de alianças estabelecidas entre grupos sociais distintos.

Phillips $^{15}$ é também crítica ao projeto de representação de grupo de Young, porque acredita na importância de acordos entre membros de diferentes grupos, mas salienta particularmente a tarefa difícil de tornar os representantes de grupos responsivos aos seus membros. ${ }^{16}$ Embora ela defenda uma política de direitos especiais por meios de cotas, essa é proposta como um meio de equiparar o acesso político dos membros de grupos oprimidos, e não como um mecanismo de representação de grupo. O foco de Phillips ${ }^{17}$ encontra-se em processos políticos institucionais e seu projeto é pela paridade na participação de homens e mulheres em fóruns político-decisórios, através da implementação de cotas. Ela acredita que mais cidadania para as mulheres implica necessariamente maior inclusão das mulheres em processos político-decisórios e implementação de políticas de gênero.

Em seu livro Inclusion and Democracy (2000), Young elucida seu argumento pela representação especial de grupos e contesta acusações de essencialismo e segregacionismo, através do conceito de perspectiva social. A perspectiva social em Young "consiste em um conjunto de questões, tipos de experiências, e pressupostos mediante os quais mais propriamente se iniciam raciocínios do que se extraem conclusões". ${ }^{18}$ A partir de diferentes perspectivas, determinadas situações e experiências teriam diferentes enfoques na vida das pessoas e seriam avaliadas de formas distintas. Alguns aspectos do processo social tornar-se-iam mais visíveis que outros e, portanto, compartilhar uma perspectiva permitiria às pessoas compreender melhor a experiência do outro e ver o contexto social e suas implicações a partir de uma situação particular. Essa afinidade não seria compartilhada por pessoas localizadas em posições sociais distintas.

Porém, as perspectivas diferentes não são necessariamente incompatíveis. A existência de uma menor afinidade não impede que pessoas que ocupem posições sociais distintas possam compreender a descrição de uma situação particular narrada a partir de outra perspectiva, ${ }^{19}$ ou seja, é apenas mais difícil, mas não é impossível, compreender a descrição de perspectivas que não sejam compartilhadas.

Young concorda com seus críticos de que aquelas pessoas que são consideradas pertencentes a grupos sociais específicos tendem a ter interesses e opiniões diversas, na medida em que elas raciocinam de forma diferente sobre suas condições e têm diferentes objetivos, mas afirma que as suas perspectivas tenderiam a se assemelhar. ${ }^{20}$ Definir a existência de diferentes perspectivas 
${ }^{21}$ YOUNG, 2000, p. 144-145.

de grupo, no entanto, não implicaria assumir identidades estanques, pois a perspectiva ajuda a captar a sensibilidade que estar posicionado em determinado campo social favorece, sendo apenas um modo de olhar que não determina o que é visto. Ela seria aquela posição a partir de onde questões são levantadas e não a partir de onde conclusões são extraídas. A perspectiva não teria, portanto, um conteúdo específico.

Os múltiplos posicionamentos sociais das pessoas não são considerados empecilhos para a ideia de perspectiva de grupo. Pessoas multiplamente posicionadas na estrutura social, de acordo com Young, teriam perspectivas mais complexas sobre as diferentes formas de opressão e desfavorecimentos, as quais contribuiriam para aperfeiçoar o modo de ver os processos sociais. Em certas situações as pessoas se sentiriam mais próximas de algumas identidades que em outras, em outros casos, as suas identidades mesclarse-iam. De toda forma, a autora alerta que devemos tomar cuidado para que, ao afirmarmos que as pessoas têm histórias plurais que são irredutíveis, não adotemos um individualismo extremo a partir do qual qualquer leitura social passe a ser vista como parcial e, portanto, inútil.

No ideal de democracia comunicativa de Young o processo político pressupõe a expressão de perspectivas diversas, o respeito pelas formas múltiplas de expressá-las e o debate entre elas. A representação especial de grupos propicia recursos para a construção de um público democrático comunicativo que tem como objetivo construir justiça. A inclusão de grupos sociais marginalizados no processo de tomada de decisão política seria um meio de intensificar a democracia, na medida em que a manifestação de diferentes perspectivas contribuiria para: a) evidenciar a particularidade das perspectivas dominantes; b) trazer novos conhecimentos para a discussão e a deliberação política; c) apresentar diferentes visões sobre as causas do problema e os possíveis impactos; e d) apresentar diferentes apreciações sobre as relações entre grupos e processos históricos. ${ }^{21}$ Assim, a inclusão de grupos em processos decisórios contribui com novas perspectivas, promovendo ações mais sensatas, novos relacionamentos e a justiça social.

Tendo parcialmente apresentado a crítica feminista acerca da organização política do estado moderno e sobre a importância de dar voz política às experiências de grupos diferentemente posicionados na estrutura social, torna-se pertinente considerar como o projeto por um aumento na influência política das mulheres e pela equidade de gênero melhor se efetivaria no modelo político atual. A organização de membros de grupos sociais não hegemônicos tanto em 
espaços cívicos quanto em fóruns políticos tradicionais pode servir de instrumento para a definição e a articulação de demandas e para a manifestação de perspectivas de grupos, que de outra forma poderiam passar despercebidas, mas ela não substitui a ação integrada entre diferentes agentes em espaços de formulação e de implementação de políicas. Na contemporaneidade, participação e influência efetiva em processos políticos implicam relacionamento próximo com as instituições representativas. Assim, considerar o tópico da representação especial de grupo a partir do debate sobre representação política é uma questão central.

\section{Representação política e representação de grupos}

A legitimidade adquirida pelo projeto de aumentar o número de mulheres em processos político-decisórios é manifestada no número crescente de países que vêm adotando cotas de gênero para diferentes níveis do governo. Apesar dessa tendência, as críticas a esse projeto são contundentes. Duas questões merecem destaque: a primeira refere-se ao caráter controverso e subjetivo do conceito de representação política. O que ou quem os representantes políticos de fato representam? A agenda política de seus partidos? Os grupos sociais aos quais pertencem? Suas bases eleitorais? Os interesses dos grupos que os elegeram? Os interesses da nação? O conceito de representação política recebe interpretações distintas de acordo com diferentes perspectivas teóricas.

A segunda questão é relativa à noção de identidade de grupo. Argumentar pela necessidade de aumentar a presença de grupos específicos em processos institucionais de decisão política como meio de assegurar maior responsividade dessa decisão aos primeiros parece assumir uma noção de identidade grupal que é dada a priori. Haveria de fato uma identidade entre mulheres, negros e membros de minorias étnicas e religiosas que os caracterizaria como sendo portadores de interesses comuns?

Os argumentos apresentados por Hanna Pitkin no livro The Concept of Representation (1967) - um clássico sobre o tópico - oferecem um bom subsídio para considerar o grupo de perguntas postas anteriormente.. Partindo de interpretações comuns sobre o conceito de representação, a autora constrói uma tipologia que envolve quatro interpretações: a) representação formalística; b) representação descritiva; c) representação simbólica; e d) representação substantiva ou representação como um ato de 'agir por' (acting for).

A representação formalística se refere às regras que organizam a representação política, dando ao representante 
${ }^{22}$ Hanna PITKIN, 1967, p. 39.

${ }^{23}$ PITKIN, 1967, p. 28.

${ }^{24}$ PITKIN, 1967, p. 55. o direito de representar (autorização) e se refere também aos processos através dos quais os representantes teriam que prestar contas dos seus atos (accountability), ou seja, este tipo de representação tem duas dimensões: a autorização e a accountability. A representação formalística é apresentada por Pitkin a partir da distinção hobbesiana entre pessoa 'natural' e pessoa 'artificial'. Segundo Hobbes, n'O Leviatã, os indivíduos no estado da natureza teriam entrado em um contrato para autorizar um deles, o soberano, a representar os demais. Com isso os representantes teriam adquirido poder e legitimidade para decidir em nome dos representados. A autora intitula essa visão de representação de "autorização", pois nela os representantes seriam autorizados a agir em nome do outro. Ainda que os representados sejam indiretamente os responsáveis pelas decisões do representante, na medida em que foi deles que partiu a autorização, é aos representantes que caberia a responsabilidade de decidir sobre que aspectos deveriam ser representados. Em sua forma extrema, a noção de autorização daria liberdade de ação aos representantes e eles atuariam como fiduciários (trustees) dos representados.

Para Pitkin, embora a autorização seja um aspecto importante da representação política, essa concepção é limitada. O foco na autorização faria com que todo representante eleito fosse considerado representativo, e uma avaliação sobre a qualidade da representação não faria sentido na medida em que, uma vez autorizado, o legislador teria liberdade para agir como bem entendesse e qualquer ato do representante seria considerado representação. ${ }^{22}$ Essa visão não considera como os representantes devem agir, o que é esperado que eles façam ou se as suas ações representativas são boas ou ruins, o que para a autora é inaceitável, pois representação não significa apenas agir com autorização de outra pessoa, e sim agir pelo interesse dela. ${ }^{23}$

Pitkin apresenta a noção de accountability como uma segunda dimensão do conceito de representação formalística, que teria como função corrigir os limites da noção de autorização. No conceito de accountability está implícito que, embora estando autorizado a agir pelo representado, caberia ao representante o dever de prestar contas e responder ao representado por suas ações. ${ }^{24} \mathrm{~A}$ accountability teria o objetivo de assegurar que o representante atuasse em nome do representado. Em alguns casos, na noção de accountability está implicado que a vontade do representado tem primazia em qualquer situação e que o representante atua como um delegado do representado, o que para Pitkin é igualmente problemático.

Um segundo modelo de representação, na tipologia de Pitkin, é a representação descritiva, espelho ou 
${ }^{25}$ PITKIN, 1967, p. 61.

${ }^{26}$ PITKIN, 1967, p. 81.

${ }^{27}$ PITKIN, 1967, p. 83.

${ }^{28}$ PITKIN, 1967, p. 90.

${ }^{29}$ PITKIN, 1967, p. 97. microcósmica. Nesse tipo de representação, segundo a autora, o representante não atua por seus representados, mas os substitui. Os espaços representativos funcionariam como microcosmos da população e haveria uma correspondência estreita entre as características do representante e as do representado. ${ }^{25} \mathrm{O}$ argumento em favor da representação descritiva seria o de que a exclusão de qualquer grupo de posições de poder pode distorcer as decisões e o conteúdo das políticas públicas. Para Pitkin, essa noção é contestável, pois, assim como um mapa não é uma representação fiel da realidade, ou mesmo um espelho não reflete de forma pura a imagem diante dele, também um representante, por mais que se assemelhe àqueles que pensa representar, não pode ser considerado uma amostra do seu grupo. Pitkin afirma que o argumento central em favor da representação descritiva é a capacidade do representante de prover informação sobre algo, ou alguém, que não está presente. ${ }^{26}$ Representar, portanto, significa dar informação sobre o representado. Ser um bom representante seria o mesmo que dar informação correta sobre o representado. No entanto, se não houver informação a ser dada, não existe a possibilidade da representação. ${ }^{27}$

Para a autora, essa forma de representação exclui o ato de "agir por" e não requer uma prestação de contas, pois uma pessoa pode apenas ser responsabilizada pelo que faz, mas não pelo que ela é. ${ }^{28}$ Como a identidade não é uma categoria objetiva, a representação descritiva não garantiria uma congruência entre as vontades dos representantes e as dos representados, mas haveria apenas uma semelhança entre eles. Além do mais, segundo a autora, os representantes são fundamentalmente diferentes em termos de status de seus representados; daí ser impossível uma correlação estreita entre os dois mesmo na representação descritiva.

Para Pitkin, a representação descritiva é indesejável pois uma ênfase na composição do corpo legislativo desviaria a atenção do que é fundamental na representação, ou seja, o seu conteúdo. Para ela, o representado está presente no ato, e não nas características do representante. Assim, mesmo que fosse possível fazer do legislativo uma amostra fiel da sociedade, isso não garantiria representação em termos de responsabilidade e responsividade com o representado.

O conceito de representação simbólica também é contestado por Pitkin, pois para ela símbolos representam alguma coisa apenas porque evocam sua referência: uma bandeira, por exemplo, representa uma nação. Símbolos são normalmente arbitrários e não precisam ter conexão óbvia com o que está sendo simbolizado. ${ }^{29}$ Símbolos não são representantes, nem perfeitos, nem imperfeitos, porque perfeição de correspondência não importa em representação 
${ }^{30}$ PITKIN, 1967, p. 102.

\begin{abstract}
${ }^{31}$ Georgia Duerst-Lahti e Dayana Verstegen (1995, p. 216-217) contestam essa visão argumentando que símbolos não são completamente desvinculados do que eles buscam representar, pelo contrário, tendem a ter uma relação estreita com eles. A bandeira dos Estados Unidos, por exemplo, tem o mesmo número de estrelas que o número de estados. Ela não poderia ter qualquer número de estrelas e continuar com o mesmo valor simbólico. Os autores fazem uma analogia com a representação por gênero para argumentar que um parlamento em que poucas mulheres estão presentes não seria simbolicamente representativo da população.

32 PITKIN, 1967, p. 153.

${ }^{33}$ PITKIN, 1967, p. 209.
\end{abstract}

${ }^{34}$ PITKIN, 1967, p. 114. simbólica. Eles não são usados como fonte de informação, em vez disso, são recipientes de sentimento e ações, dirigidos ao que representam. A base da representação simbólica seria emocional e afetiva; seria uma resposta psicológica irracional e, portanto, não justificável. ${ }^{30} \mathrm{O}$ critério de avaliação em representação simbólica é se os representados creem no representante. Não existem critérios racionais para que se possa julgar o caráter da representação e nenhuma necessidade de que o representante atue pelo representado. ${ }^{31}$

A representação substantiva é o modelo de representação defendido por Pitkin. Sua definição é similar à de Edmund Burke e John Stuart Mill, quando afirma que os representantes não devem ser constrangidos pelos representados. Em sua opinião, a representação implica que o representante deve ter certo grau de liberdade para agir, porém não deve estar persistentemente em contradição com os representados. ${ }^{32}$ Ao mesmo tempo, agir pelos representados não significa que os representantes apenas exerçam a representação quando estiveram de acordo com as suas vontades. Pelo contrário, liderança e ações emergenciais em assuntos sobre os quais as pessoas sabem pouco ou nada seriam importantes funções do governo representativo. Isso seria a própria essência da representação. No entanto, sob condições normais, os desejos dos representados e as ações dos representantes deverão convergir. Pitkin define representação como "agir pelo interesse dos representados, de forma a ser responsivo a eles". ${ }^{33} \mathrm{O}$ sistema representativo deveria ser responsivo às opiniões públicas, exceto quando o não ser responsivo fosse justificável com respeito à própria defesa do interesse público. Este modelo de representação é, em grande medita, acolhido por muitos autores contemporâneos.

Os argumentos utilizados para discutir representação, segundo Pitkin, concentram-se normalmente na relação entre os representantes e os representados, mas na verdade as pessoas se comportam de forma diferente quando estão agindo em nome de outros. ${ }^{34}$ Poucos teóricos, segundo ela, focam no ato de representar em si, ou seja, na substância da representação, na atividade da representação política e em seus atributos. Mas a verdadeira função do representante consistiria em fazer avaliações independentes, sabendo e antecipando o que os eleitores desejam. Assim, uma função importante do representante seria sua capacidade de julgar o que é melhor para os representados independentemente.

Um agente importante na representação política, apenas timidamente presente na discussão de Pitkin, são os partidos políticos. Nos sistemas partidários os representantes são normalmente levados a votar com seus partidos, mesmo 
que aparentemente contrariando os interesses dos eleitores. Com base nisso, muitos poderiam concluir que o projeto partidário teria primazia sobre as ideias e a vontade do representante. Assim, o que importaria de fato em representação política seria o partido ao qual o representante pertence e não quem ele/ela é ou suas ideias. Porém, assim como a relação entre representante e representado não deve ser vista como sendo de mera autorização ou de prestação de contas, mas como uma relação mediada entre representantes e representados, defender a influência dos partidos sobre a ação dos representantes não implica assumir total submissão destes últimos aos primeiros. Os representantes têm também poder para influenciar os partidos e em alguns casos eles têm relativa independência dos partidos. Assim, as ideias e a agenda partidária não são os únicos fatores determinantes. Quem é o representante, qual a sua procedência, quais as suas convicções e experiências são fatores também importante para influenciar o conteúdo da representação.

\section{Representação descritiva e representação substantiva}

O debate atual em favor da representação especial de grupos é articulado primordialmente através da discussão sobre a relação entre representação descritiva e representação substantiva. A exemplo de Pitkin, alguns autores se posicionam contrariamente à representação descritiva, pois entendem que o mais importante é o que os representantes fazem, e não quem eles são. $O$ foco do argumento encontra-se no aspecto substantivo da representação, e a presença física de membros de grupos sociais distintos não é considerada uma condição para que seus interesses sejam representados. O principal objetivo do corpo legislativo seria o de representar interesses públicos de seus eleitores e, assim, um bom representante seria aquele que melhor defendesse os interesses dos seus representados e fosse mais responsivo a esses. Consequentemente, os representantes deveriam ser escolhidos por seus méritos, ou seja, por suas ideias e capacidades de articulação política, e não por suas características individuais e por seus traços físicos. O problema, no entanto, é como especificar responsividade, dado o caráter diverso e conflituoso dos interesses sociais.

Em Pitkin são reconhecidos o problema inerente à noção de responsividade e representatividade, devido à impossibilidade de objetivação de interesses, e o distanciamento do representante do representado, dada a peculiaridade da função representativa. Porém, a autora não aprofunda essa discussão e argumenta que não há 
${ }^{35}$ YOUNG, 2000.

${ }^{36}$ YOUNG, 2000, p. 129.

${ }^{37}$ YOUNG, 2000, p. 144. necessidade de que os representantes deem resposta constante aos seus representados. O que é necessário, segundo ela, é que haja condições constantes para que eles sejam responsivos.

Pensando nas condições de accountability, Young ${ }^{35}$ advoga a ampliação dos espaços de prestação de contas, pois acredita que nas democracias atuais o momento da accountability é negligenciado. Para Young, a representação política é um processo contínuo que se realiza em diferentes momentos, através de um relacionamento mediado entre representantes e representados, dos representados entre si e entre os representantes no espaço decisório. ${ }^{36}$ Para além do período eleitoral, que tende a se constituir no principal ou único meio de prestação de contas através da reautorização, seria necessária a criação de processos e mecanismos pelos quais os eleitores pudessem chamar seus representantes para prestarem contas. Esses espaços conduziriam à maior troca entre ambos, resolvendo o problema comum de afastamento do representante de suas bases após as eleições, e se constituiriam em novos momentos de autorização. A autora destaca que, quando os eleitores se tornam muito distantes dos representados, eles acreditam que não exercem influência, se desafeiçoam e perdem interesse em participar politicamente, ${ }^{37}$ daí ser imprescindível se pensarem processos de ampliação do momento da accountability, que poderiam ocorrer tanto nos espaços oficiais como na sociedade civil.

Outro debate central sobre representação substantiva e representação descritiva refere-se à questão do mérito. A noção de que os representantes devam ser escolhidos por suas habilidades políticas tem preponderante consentimento, mas é necessário que se questione em que medida a seleção por mérito é desvinculada da seleção por grupo. Como discutido anteriormente aqui, as normas que governam as esferas políticas não são neutras e, assim, os critérios ditos subjetivos de julgamento do mérito são normalmente favorecedores daqueles que mais se assemelham às características do grupo selecionador. Destarte, faz-se necessário avaliar se processos de seleção supostamente neutros e baseados no mérito não seriam permeados por julgamentos parciais de aspectos e características do candidato, os quais seriam mais facilmente manifestos em grupos específicos.

Jane Mansbridge argumenta que a principal crítica à representação descritiva se dá principalmente pela confusão feita entre duas formas distintas desse modelo: a microcósmica e a seletiva. ${ }^{38}$ No primeiro caso, o espaço de representação se apresenta como uma amostra da população e, no segundo - mais frequentemente presente 
${ }^{39}$ MANSBRIDGE, 1999.

${ }^{40}$ MANSBRIDGE, 1999. nos argumentos a favor da representação descritiva -, o objetivo seria pela implementação de mecanismos institucionais que criassem mais espaços representativos para alguns grupos do que eles conquistariam pelas vias tradicionais, de forma a fazer com que a proporção dos membros desse grupo presente no espaço legislativo se aproximasse do seu número na população. ${ }^{39}$ Tal representação seria necessária apenas quando algum fator do processo de seleção de um sistema operasse para reduzir o número de representantes de certos grupos. No Brasil, por exemplo, embora as mulheres representem em torno de $52 \%$ dos eleitores e da população, o número de mulheres presentes na Câmara dos Deputados não chega a 10\%, ou seja, esse grupo qualificaria para uma representação especial no espaço mencionado, mas nem todo grupo social, como, por exemplo, pessoas que gostam da cor rosa ou torcedores do Corinthians, como alguns críticos dessa posição parecem querer levar a crer.

Outro contraponto diz respeito à visão de desconexão entre representação descritiva e representação substantiva. Mansbridge, ${ }^{40}$ concordando com Pitkin, afirma que o papel principal da democracia representativa é o de representar os interesses substantivos dos representados por meio das funções deliberativas e agregativas. Mas propõe que a representação descritiva seja julgada prioritariamente por esses dois critérios. A pergunta a ser feita é se o caráter deliberativo e agregativo da democracia requer a participação de representantes de diferentes perspectivas para que se possa representá-las. Segundo a autora, a resposta a essa pergunta deve ser contextualizada, mas no geral, tanto em processos deliberativos (que pressupõem a manifestação de diferentes perspectivas e interesses de variados grupos) quanto em processos agregativos (que buscam equiparar e balancear interesses conflitivos), a representação de diferentes perspectivas seria mais bem servida por representantes descritivos. No primeiro caso, porque as pessoas tendem a conhecer melhor sobre seus próprios interesses e, portanto, seriam mais indicadas para reconhecêlos, articulá-los e proporem soluções; no segundo, porque elas tendem a dar mais ênfase aos seus próprios interesses, defendendo-os, assim, com mais veemência. Esse argumento será explorado mais à frente neste artigo.

O argumento que pressupõe uma relação automática entre as experiências do representante e seus projetos políticos é certamente contestável. Mas, na medida em que as ideias das pessoas não estão dissociadas de suas vivências materiais, uma composição mais plural dos espaços político-decisórios, em que diversos grupos sociais estejam representados, propiciaria a expressão de diferentes 
${ }^{41}$ PHILLIPS, 1995, p. 25.

${ }^{42}$ Virginia SAPIRO, 1998, p. 183.

${ }^{43}$ Marian SAWER, 2000. perspectivas, favorecendo a construção de políticas mais voltadas a interesses e necessidades sociais mais amplas. Em se tratando de representação política, como afirma Anne Phillips, "é no relacionamento entre ideias e presença que nós temos mais chances de encontrar um sistema mais justo de representação". ${ }^{41}$

\section{A política de cotas}

A política de cotas é o principal mecanismo proposto pelos que advogam a paridade de gênero em esferas legislativas. São quatro os principais argumentos utilizados em favor das cotas (ou do aumento na presença de mulheres em cargos político-decisórios), os quais coincidem com as perspectivas apresentados por Pitkin sobre os tipos de representação. Eles são: 1) argumento pelo simbolismo de um aumento no número de mulheres na política; 2) argumento por justiça, por meio do qual é afirmado que não é justo que, sendo as mulheres mais ou menos $50 \%$ da população, os homens monopolizem as decisões políticas; 3 ) argumento da diferença, que considera que as mulheres são diferentes dos homens, mais éticas e honestas, e que podem contribuir para mudar a política; e 4) argumento pela importância da experiência de vida, visto que as mulheres tendem a ter experiências de vidas distintas dos homens e podem tornar o processo político mais representativo dos interesses e das perspectivas de setores sociais mais amplos.

A defesa da importância simbólica das cotas se sustenta na visão de que um aumento no número de mulheres em cargos legislativos teria uma função cultural, na medida em serviria como exemplo para outras mulheres seguirem a carreira política e contribuiria para mudar percepções estabelecidas sobre a competência política das mulheres. Referindo-se a esse debate, Sapiro comenta: "Mulheres e homens continuam pensando a política como um espaço masculino porque a verdade empírica do momento é que a política é um espaço masculino". ${ }^{42}$ De fato, considerandose o número pequeno de mulheres que ocupam posições legislativas e executivas no mundo, e no Brasil particularmente, não surpreende que as mulheres vejam as esferas políticas tradicionais como sendo distantes e inacessíveis a elas. Outro argumento pelo simbolismo é o de que um acréscimo de mulheres em posições legislativas favoreceria uma aproximação entre representantes e representados, na medida em que é mais provável que mulheres atuantes nos movimentos sociais busquem apoio nas mulheres parlamentares para suas demandas. ${ }^{43}$

Phillips considera o argumento pela representação simbólica pouco relevante, pois ele não estaria diretamente 
${ }^{44}$ PHILLIPS, 1995, p. 63.

${ }^{45}$ Sobre esta questão, ver Teresa SACCHET, 2008.

${ }^{46}$ PHILLIPS, 1995.

${ }^{47}$ PHILLIPS, 1995, p. 63

${ }^{48}$ Estritamente falando, não se pode considerar que a política de cotas seja o único instrumento necessário para nivelar o campo de disputa. As cotas se constituem no ponto de partida para a igualdade política, mas a questão da engenharia eleitoral (particularmente o tipo de sistema eleitoral e de lista) e os recursos de campanha são dois outros elementos centrais - os quais, por sua vez, estão relacionados a outros obstáculos de ordem socioeconômica e cultural, ou seja, um nivelamento no campo de disputa implicaria também a revisão dos instrumentos e das leis que regulamentam as eleições e seus recursos com o intuito de aumentar a participação política das mulheres. Sobre isso, ver Teresa SACCHET e Bruno SPECK, 2010.

${ }^{49}$ PHILLIPS, 1995, p. 64. associado ao tópico da representação política e, portanto, não teria um valor político intrínseco. ${ }^{44}$ Porém, ainda que não diretamente relacionados ao tópico da representação política, simbolismos carregam em si importantes potenciais políticos. Em sociedades estruturadas por relações de gênero desiguais, em que um número elevado de mulheres estão ausentes de cargos de tomada de decisão política, contribuindo para que o público eleitor, e elas mesmas, as percebam como menos capacitadas politicamente, medidas que encaminhem mudanças de percepções nesse âmbito têm uma importante função política. A natureza polêmica da política de cotas e a sua habilidade para alterar a composição de gênero do corpo legislativo impelem debates e embates que ajudam a explicitar desigualdades e discriminações de gênero. ${ }^{45}$ Mas, ainda que um aumento das mulheres na política possa auxiliar na construção de novos valores e perspectivas de gênero, contribuindo para a equidade de gênero em esferas sociais e políticas, o impacto simbólico das cotas não se constitui no principal argumento pela implementação dessa política.

O segundo argumento é de que o desequilíbrio na presença de mulheres e homens em cargos decisórios revela injustiça, na medida em que as primeiras compõem em média mais de $50 \%$ da população, mas são representadas politicamente em percentagens bem inferiores. Diante da existência de igualdade formal, isso seria indicativo da ausência de igualdade substantiva. Esse argumento articula uma noção de igualdade formal com a de igualdade substantiva, explicitando a existência de impedimentos concretos à representação política das mulheres. ${ }^{46}$ Se não houvesse obstáculos estruturais, políticos ou culturais, seria de se esperar que o número de representantes dos dois sexos fosse mais ou menos equilibrado. O fato de os homens predominarem nas posições político-decisórias proporciona evidência de "discriminação intencional ou estrutural". ${ }^{47} \mathrm{~A}$ política de cotas seria assim justificada no argumento da igualdade substantiva, ou seja, em sociedades democráticas em que as pessoas têm os mesmos direitos formais, mas são impedidas de exercê-los igualmente por motivos de desigualdades econômicas, sociais ou por discriminação, as cotas seriam um artifício necessário para nivelar o campo da disputa entre homens e mulheres. ${ }^{48}$

Todavia, o argumento por justiça não oferece uma defesa normativa que justifique uma participação paritária entre homens e mulheres nas esferas de tomada de decisão política. Phillips argumenta que representação é um ato político e "ser um político não é como outro tipo de trabalho qualquer" ${ }^{49}$ A função de representação envolve o ato de representar, e não pode ser considerada apenas como 
50 Luís Felipe MIGUEL, 2001; e PHILLIPS, 1995.

${ }^{51}$ Phillips atribui às mulheres a tendência a uma agenda mais voltada para o social como proveniente de suas experiências particulares de vida, enquanto Miguel salienta que ela decorre do fato de ser esse o "único nicho disponível para elas no campo político" (2001, p. 261). Este autor acredita que, com um aumento no número de mulheres em posições legislativas, essas diferenças desapareceriam.

52 MIGUEL, 2001. questão de direito individual. Um tópico corrente, já apresentado aqui nos argumentos de Pitkin e defendido por vários autores, é que em representação política o mais importante é o conteúdo da representação, e não quem é o representante. Portanto, o que todos parecem querer saber, no fim das contas, é se uma nova composição do corpo parlamentar faria alguma diferença no conteúdo da representação política. Essa discussão será retomada em breve.

O terceiro argumento é aquele que estabelece que as mulheres têm identidades e experiências distintas e que, portanto, podem melhorar a política. Um aumento no número de mulheres nas esferas representativas seria um catalisador de mudanças, na medida em que as mulheres introduziriam novos comportamentos e valores. Nessa visão as mulheres seriam essencialmente diferentes dos homens: mais éticas, menos competitivas, menos corruptas, mais solidárias e assim por diante. Tal posição é normalmente associada ao papel da mulher como mãe como sendo naturalmente bom. Mas não é evidente por que a maternidade faria das mulheres melhores representantes, já que a relação entre mães e filhos não é uma relação a ser copiada na esfera parlamentar, sendo uma relação de parcialidade e de desigualdade. ${ }^{50}$

Ainda que um acréscimo no número de mulheres em fóruns políticos deva gerar mudanças em suas culturas internas e agendas, como assinalam Phillips e Miguel, ${ }^{51} \mathrm{O}$ argumento de que as mulheres melhoram a política não pode ser sustentado e é pouco recomendável, na medida em que essencializa as suas diferenças e difunde uma visão específica sobre as mulheres que pode fortalecer a perspectiva da sua inabilidade para o exercício da função pública. Miguel ${ }^{52}$ opõe-se à valorização do que ele chama de "política do desvelo" nas mulheres por diferentes motivos, mas destaca o fato de que, ao legitimar a visão das mulheres como responsáveis pelo cuidado, tal perspectiva acena para a negação dos seus direitos individuais. O reforço e a valorização de tais atributos nas mulheres comprometem o processo de mudança nas relações de gênero e limitam a capacidade de ação e transformação do sujeito feminino. Assim, o discurso que fixa as diferenças é pouco recomendável para o propósito da promoção política das mulheres e para a igualdade de gênero.

O quarto, e último argumento, é o que afirma que, em uma sociedade pluralista, existe uma multiplicidade de interesses que necessitam tanto de reconhecimento como de controle social. Uma forma de assegurar que diferentes opiniões e perspectivas sejam ouvidas e de limitar excessos de poder é garantir espaço para que membros de grupos sociais distintos participem em processos político-decisórios. 
53 MANSBRIDGE, 1999; e PHILLIPS, 1995.

${ }^{54}$ PHILLIPS, 1995 e 1999.
A democracia pressupõe a representação de uma pluralidade de perspectivas e de interesses nas esferas representativas, e a inclusão política das mulheres é, por conseguinte, uma de suas condições. Aqui a demanda por um aumento na participação das mulheres em processos de tomada de decisão política ganha consistência no conhecimento das pessoas sobre seus próprios interesses e na ênfase que elas podem dar a seus interesses. O grau de envolvimento das mulheres com certas questões da vida social as torna mais capacitadas para identificar temas excluídos ou pouco representados na esfera política e faz delas melhores defensoras dos seus interesses - ainda que não haja garantia de que as mulheres assumam tal papel..$^{53}$ Nesse sentido, a experiência de vida é um elemento que potencializa a boa representação, qual seja, uma que incorpore interesses, visões e perspectivas de diversos grupos sociais.

Uma das principais objeções a essa visão é de que ela essencializa interesses de membros de grupos sociais, os quais seriam múltiplos. Se identidades não são estanques e interesses não são objetivamente definidos, um questionamento que se coloca é se faria alguma diferença aumentar a presença de mulheres no processo político-decisório. Outra crítica é a de que a presença dos membros de um grupo não assegura o caráter substantivo da representação, pois a esfera legislativa é um espaço distinto em que interesses se constituem e são articulados, e os representantes, por sua vez, formam um grupo à parte.

As respostas a esses dois contrapontos são articuladas através de suas lógicas internas. Com relação ao primeiro, o argumento é de que, se interesses fossem objetivamente definidos e todos soubessem que políticas melhor atenderiam aos interesses de grupos específicos, qualquer desequilíbrio em termos de direitos poderia ser contestado e não existiria necessidade de representação especial. ${ }^{54}$ Esse raciocínio reverte à lógica principal do argumento contra a representação de grupos, fazendo com que a impossibilidade da definição objetiva de identidades e interesses, empregada contra essa demanda, transforme-se no próprio argumento pela representação de grupos.

Sobre o segundo contraponto, qual seja, o da diferenciação entre representantes e representados, a réplica é similar e o argumento é de que é exatamente porque interesses não são apenas representados, mas também definidos, disputados e articulados nas esferas políticas, que há necessidade de maior participação de membros de diferentes grupos sociais, os quais teriam mais habilidade para exercer tais funções a partir das perspectivas de seus grupos. Ainda que membros de grupos distintos possam representar interesses de membros de outros grupos, é mais 
${ }^{55}$ PHILLIPS, 1995. difícil para as pessoas entenderem experiências e perspectivas que se originam de localizações sociais muito distintas. Assim, as mulheres seriam melhores articuladoras e defensoras dos interesses do seu grupo. ${ }^{55} \mathrm{~A}$ inclusão de membros de grupos sociais em processos políico-decisórios tem um potencial para democratizar a definição da agenda pública, na medida em que suas experiências múltiplas contribuem para colocar novos assuntos em pauta, para uma leitura de questões políticas em geral a partir de diferentes ângulos, enquanto ao mesmo tempo podem fornecer soluções distintas, por vezes mais apropriadas, para essas questões.

O conceito de perspectiva social é pertinente neste debate. A noção de perspectiva, pensada como o olhar que membros de grupos similarmente posicionados na estrutura social dividem, favorece a demanda por um aumento na representação das mulheres em esferas legislativas, na medida em que estabelece uma relação entre a experiência de vida das pessoas e as leituras que elas fazem do mundo à sua volta.

Pensemos na seguinte situação hipotética: a administração pública de uma pequena cidade recebe um montante significativo de recurso financeiro de um organismo internacional para ser empregado em projetos de melhorias infraestruturais e em iniciativas sociais e culturais. Uma das exigências do órgão doador é de que o investimento da verba seja decidido através de processos consultivos envolvendo os moradores da cidade. É criado assim um comitê de consultores, os quais, inadvertidamente, são todos homens brancos e de classes sociais mais favorecidas - um arranjo comum em escolhas espontâneas em que não há preocupação com a composição do grupo.

Tendo tal comitê sido contestado por membros de grupos da sociedade civil por tamanha homogeneidade de sua composição, a prefeitura resolve criar um segundo comitê mais pluralmente constituído, do qual participam também representantes indicados por esses organismos para atuar paralelamente ao primeiro. O novo comitê tem o mesmo número de integrantes que o primeiro, mas desta vez metade deles é de mulheres. Dentre o grupo dos homens e das mulheres há uma proporção mais ou menos equilibrada de negros e de brancos, de membros da classe média e da classe trabalhadora, alguns são gays e lésbicas, e há pessoas com deficiência e de diferentes faixas etárias.

Imaginemos o resultado dos processos deliberativos que se originariam desses dois comitês e dificilmente iremos supor que eles seriam iguais. Ainda que as propostas desses dois grupos dependessem das condições e das articulações específicas do local e do momento da deliberação, é mais 
provável que as sugestões do segundo comitê, por terem se originado através de um processo consultivo mais inclusivo, envolvendo membros de diferentes grupos sociais, fossem mais expressivas das necessidades e dos interesses de uma pluralidade maior de grupos. É mais provável que as suas deliberações incluíssem propostas para a construção de rampas de acesso para cadeirantes e para carrinhos de bebês em espaços públicos; corrimões para favorecer a locomoção de pessoas de idade mais avançada em áreas íngremes; iniciativas para a ampliação de creches e escolas de tempo integral; elaboração de material didático com o propósito de reconhecer diferentes sexualidades e culturas étnicas etc.

O exemplo anterior simplifica uma situação complexa, na medida em que os processos deliberativos de fóruns políticos envolvem modelos distintos de tomada de decisão, nos quais estão imbricados questões e interesses não necessariamente articulados naquele espaço ou diretamente associados à experiência de vida dos representantes, mas dos quais alguns deles se tornam defensores através do sistema eleitoral e partidário. Mesmo evitando uma visão dos representantes como defensores de interesses preestabelecidos, seria demasiadamente ingênuo assumir que as agendas públicas são formadas exclusivamente a partir de processos abertamente deliberativos em que vencem os argumentos mais coerentes ou de maior força argumentativa. O exemplo apresentado anteriormente, no entanto, serve como um exercício de imaginação que favorece a compreensão sobre o papel e a importância da diversificação da composição social do corpo deliberativo para trazer à tona perspectivas excluídas ou pouco representadas.

Favoritismos políticos e sociais fazem com que alguns interesses sejam deliberadamente eliminados da agenda pública, enquanto outros sejam afiançados. Nesse caso, a presença de membros de diferentes grupos pode contribuir para limitar a preponderância de certos interesses na agenda política e para advogar e articular outros. Mas, mesmo onde não há discriminação intencional, a exclusão da perspectiva de grupos sociais de processos deliberativos conduz à invisibilidade de questões pertinentes às suas experiências de vida, que consequentemente acarretam em falta de reconhecimento e injustiças na distribuição dos recursos públicos. A inclusão de diferentes grupos no processo decisório favorece a expressão e o reconhecimento de perspectivas diversas, potencializando a construção de políticas mais voltadas para necessidades e interesses de uma variedade maior de grupos. 


\section{Conclusões: representação especial de grupos, cotas e a questão do essencialismo}

A representação especial de grupos e a política de cotas enfrentam críticas por parte de diferentes tradições políticas. Esses projetos são opostos pelos liberais pela ênfase que eles dão à neutralidade e ao princípio da igualdade jurídica. Aqui as diferenças não devem contar, pois todos são, presumidamente, iguais perante a lei e a justiça se efetuaria através da aplicação de regras gerais e imparciais. Um argumento frequente utilizado extensivamente por opositores das cotas de gênero e raciais (para vagas nas universidades) no Brasil é de que essa medida é uma discriminação ao contrário, pois desrespeita o princípio democrático da igualdade.

Essa visão se baseia numa noção restrita de igualdade em que as políticas de ações afirmativas são vistas como medidas que criam privilégios. No entanto, políticas de ações afirmativas, e as cotas mais especificamente, são criadas a partir da contextualização das desigualdades entre grupos sociais específicos. Na maioria das vezes essas políticas voltam-se às mulheres e aos membros de minorias étnicas e raciais, pois são esses grupos que tendem a enfrentar mais desvantagens sociais, econômicas, políticas e culturais. Porém, em certos casos, os beneficiários são membros de grupos tradicionalmente identificados como mais favorecidos. Na Jamaica, por exemplo, dado que a evasão escolar é maior entre crianças do sexo masculino, os programas oficiais que visam aumentar $o$ atendimento das crianças às aulas têm nos meninos o seu público-alvo. O propósito dos direitos especiais é a equiparação de direitos entre grupos, e não a criação de privilégios.

Uma crítica comum à representação especial de grupos é de que ela estimula a separação, destacando os interesses particulares em detrimento da negociação e do entendimento entre os diferentes interesses. A noção de que grupos não possam se tornar aliados quando seus interesses não sejam iguais pressupõe uma visão de indivíduo racional e autointeressado, incapaz de sentimentos de empatia e de atos de solidariedade, que mais se assemelha, por assim dizer, com uma perspectiva tradicionalmente masculina. No entanto, a ideia de esquecer as diferenças em nome de um indivíduo abstrato ou em nome do bem comum (no caso do republicanismo), quando alguns grupos específicos detêm o poder econômico, cultural e político, é projeto igualmente contestável. Enquanto não haja condições de os cidadãos participarem indistintamente em pé de igualdade do processo de tomada de decisão política, a proposta de inclusão política de grupos marginalizados por meio de medidas 
56 Zillah EISENSTEIN, 1981; OKIN, 1989; e SAPIRO, 1998. Pippa Norris e Joni Lovenduski (1995, p. 115) argumentam que, "Devido a divisão convencional do trabalho na família, segregação no mercado de trabalho e padrões tradicionais de socialização, é esperado que muitas mulheres tenham menos recursos de tempo e dinheiro, e um nível mais baixo de ambição e confiança política".

${ }^{57}$ Lúcia AVELAR, 1996. especiais pode constituir-se no único instrumento efetivo para alterar a composição do corpo legislativo e para impulsionar mudanças substantivas em diferentes esferas. A aliança política entre grupos não pressupõe a construção de uma vontade coletiva eliminando a necessidade de distinguir as suas diferenças, ao contrário, um processo verdadeiramente inclusivo precisa incorporar as especificidades das experiências e das condições sociais de distintos grupos marginalizados.

Um questionamento importante das feministas marxistas é até que ponto as cotas seriam um projeto efetivo para a inclusão política das mulheres. A ideia aqui é de que o principal obstáculo à participação e à representação política das mulheres se localiza em estruturas externas à esfera política. A estrutura familiar, por exemplo, um dos pilares do desenvolvimento da sociedade capitalista, é organizada a partir de uma divisão desigual de tarefas entre homens e mulheres, responsável por gerar iniquidades de recursos e desigualdades de gênero tanto na esfera econômica quanto na política. ${ }^{56}$ Assim, um projeto focado na esfera política seria equivocado.

A esfera doméstica e a unidade familiar são focos historicamente centrais do debate feminista. John Stuart Mill, por exemplo, no livro The Subjugation of Women, argumentou que a responsabilidade das mulheres com a esfera doméstica obstaculiza suas conquistas no mundo das artes e da ciência. Segundo o autor, mesmo aquelas mulheres que teriam "serventes" seriam prejudicadas, pois é esperado delas que seu tempo e pensamento estejam à disposição dos membros da família.

A socialização das mulheres para o cuidado e para a autorrealização na vida familiar contribui para moldar suas ambições políticas e percepções sobre suas habilidades para o exercício de tal função, enquanto ao mesmo tempo cria obstáculos concretos para o seu envolvimento com a vida pública. A influência das responsabilidades domésticas e familiares na carreira política é observada em dados empíricos de pesquisas, que revelam um perfil distinto (relacionado à idade e ao estado civil) dos homens e das mulheres que compõem o corpo parlamentar. ${ }^{57}$ Portanto, se um dos impedimentos centrais ao envolvimento político das mulheres é o papel que elas desempenham na esfera doméstica, transformar as relações familiares e criar políticas públicas mais pertinentes não seriam objetivos anteriores ao de ampliar os espaços de participação política?

O importante, no entanto, é considerar como essas mudanças ocorreriam e quem estaria interessado nelas. Phillips argumenta parecer inconcebível que um legislativo 
${ }^{58}$ PHILLIPS, 1999, p. 34.

59 Judith BUTLER, 1995; e Joan Wallach SCOTT, 1988.

${ }^{60}$ PHILLIPS, 1999, p. 40.

${ }^{61}$ PHILLIPS, 1999, p. 40. composto em sua maioria de homens implemente as medidas necessárias e se empenhe para modificar o sistema de gênero e a divisão sexual do trabalho na esfera doméstica. ${ }^{58}$ Ao que tudo indica, as chances são grandes de que essas não seriam consideradas medidas prioritárias por tal corpo parlamentar. Assim, começar mudando os que definem as políticas pode ser uma boa iniciativa para promover a equidade de gênero em outras esferas.

Um dos argumentos centrais contra as cotas e para o qual não há repostas conclusivas é aquele que articula a crítica a essa medida através da noção de essencialismo. O argumento é de que membros de um mesmo grupo possuem experiências, identidades e interesses múltiplos, e seria, portanto, arbitrário destacar alguns como sendo mais próprios do grupo. As mulheres, por não formarem um grupo homogêneo na medida em que são de diferentes classes, raças, religiões, idades, afiliações partidárias etc., teriam interesses e perspectivas distintas. A ideia de identidade grupal é contestada por exagerar as similaridades entre seus supostos membros e favorecer a fixação de diferenças, que deveriam ser vistas como em processo constante de mudança. Dada a multiplicidade de experiências, de valores e de interesses das mulheres, seria impossível definir o que a categoria "mulher" significa e, consequentemente, por que a representação especial das mulheres justificarse-ia. A pergunta sobre como as mulheres poderiam ser mais bem representadas seria uma preocupação essencialista, e a fixação do sujeito é considerada arbitrária e opressiva..$^{59}$

Phillips argumenta que há diferença entre a proposta de "incluir/representar/reavaliar um grupo" e a de "incluir/ representar/reavaliar seus membros", 60 e afirma que a maioria dos argumentos para aumentar a proporção de mulheres ou representantes de minorias nos espaços de tomada de decisão é do último tipo. Essas duas noções implicariam percepções distintas sobre a representação política. Na primeira haveria um pressuposto corporatista de representação: espera-se que os representantes representem os interesses dos grupos que os elegeram; eles seriam portavozes dos interesses e das perspectivas desses grupos. A segunda, no entanto, é fundada na visão de que as pessoas que compartilham uma característica de grupo são subrepresentadas e, portanto, têm maior necessidade de representação. A reivindicação por maior presença política dos membros de um grupo não seria uma reinvindicação pela representação dos interesses desse grupo, mas por "uma distribuição mais equânime de posições representativas entre os diferentes grupos sociais que trazem uma maior variedade de perspectivas". 61 
62 Kate NASH, 1998.

${ }^{63} \mathrm{NASH}, 1998$, p. 48.
O projeto pela representação de grupo como meio de diversificar as perspectivas sociais no processo decisório parece responder à acusação de essencialismo, na medida em que não está embasado no conceito de identidade. Assim, o argumento pela representação de grupos não necessitaria ser articulado através de uma noção forte de identidade e de interesses comuns, mas no argumento sobre a necessidade de se diversificarem as perspectivas sociais presentes nos espaços político-decisórios. Porém, ainda que essa noção relativize, até certo ponto, a questão da identidade grupal, ela não a resolve por completo.

$\mathrm{Nash}^{62}$ argumenta (a meu ver corretamente) que qualquer posição que reivindica benefícios especiais, tanto para grupos quanto para membros de grupos, implica uma noção de "commonality" entre os membros de um grupo e é, portanto, essencializante. ${ }^{63}$ Ela sugere uma saída para esse debate circular sobre o essencialismo propondo ultrapassálo, focalizando na discussão sobre estratégia. A autora argumenta que, já que não é possível defender o ponto de vista da representação de grupos sem definir um sujeito (ainda que se trate de uma noção fluida), é melhor aceitar que esse é um dos limites necessariamente enfrentados pelas políticas favoráveis à representação de grupos. Para ela, a questão a ser considerada é outra: devemos pensar sobre o que é estrategicamente mais apropriado, levando em conta o que pode ser alcançado por meio das cotas, e depois nos perguntarmos se vale a pena assumirmos o essencialismo. A resposta dela para essa ponderação é negativa.

Conforme afirmado pela própria Phillips, aumentar a presença das mulheres nos organismos de representação política não traz garantia de resultados. Phillips também argumenta que as cotas podem aumentar o número de representantes mulheres sem que haja necessariamente uma mudança social e econômica que favoreça as mulheres. Ponderando essas interpretações de Phillips, Nash acredita que o preço das cotas é alto demais. Inexistindo garantias de que as cotas irão de fato alterar a vida das mulheres comuns, mas, por outro lado, elas podem contribuir para congelar as suas identidades, criando um estereótipo popular das mulheres na política como um grupo especial - talvez até como incompetentes - e consequentemente dificultando mudanças em outras áreas, ${ }^{64}$ Nash acredita que a política de cotas pode atrapalhar mais que contribuir para a autonomia das mulheres. Ou seja, não é ao essencialismo propriamente que Nash se opõe - já que ela julga ser esse inevitável em propostas pela representação de grupos -, mas à política de cotas como projeto estratégico.

A ponderação de Nash, entretanto, sobre o valor estratégico das cotas é baseada em uma análise deslocada. 
${ }^{65}$ Sobre cotas na Índia, ver Shirin RAI, 1999; e Vicky RANDALL, 2006; e, sobre cotas na África do Sul, ver Louise VINCENT, 2002.

66 Para uma discussão teórica sobre cotas e avaliação de sua implementação no Brasil, ver Clara ARAÚJO, 2001 a e 2001 b; e MIGUEL, 2000.

\footnotetext{
${ }^{67}$ Sobre o impacto da política de cotas no Brasil para além da questão numérica, ver o artigo Beyond Numbers, de Sacchet (2008).

${ }_{68}$ Nancy FRASER, 1995 e 1997.
}

Para considerar os resultados de certas políticas, é pertinente que concentremos em processos políticos e institucionais, em vez de em teoria política. No âmbito da defesa normativa, Phillips posiciona-se a favor das cotas com base em um quadro de probabilidades em vez de certezas, e isso me parece correto, pois não seria possível ou aconselhável prever resultados políticos desconsiderando o contesto e a interferência das lutas específicas resultantes de suas relações de poder. Se os processos políticos dependem também de negociações travadas dentro das arenas políticas, seus resultados, mesmo quando altamente previsíveis, são incertos. Uma melhor apreciação da pergunta sobre a relevância da política de cotas precisa ser contextualizada. Os resultados de tal política devem ser julgados de acordo com cada contexto e momento específico.

A institucionalização das cotas serviu para incrementar a representação das mulheres em alguns países, como, por exemplo, nos escandinavos e na América Latina particularmente na Argentina e na Costa Rica -, influenciando mudanças positivas para as mulheres em outras áreas. Noutros contextos, elas favoreceram um aumento no número de mulheres em instâncias representativas, mas trouxeram algumas consequências indesejáveis de divisão, como, por exemplo, na Índia e nos primeiros anos de sua implementação também na África do Sul. ${ }^{65}$ No Brasil, a implementação das cotas não atingiu sequer o seu objetivo mais imediato, que é o de aumentar a presença de mulheres em cargos legislativos. ${ }^{66}$ Portanto, ainda que generalizações possam ser feitas sobre as cotas como projeto político, não podemos fazer o mesmo sobre os seus resultados, já que esses dependem de fatores políticos e estruturais específicos a cada contexto. Às vezes os resultados podem dissentir do seu projeto original, como podem também provocar consequências que não foram intencionadas. Mas, mesmo em casos de aparente fracasso, como o brasileiro, a implementação de cotas é considerada positiva por mulheres em instituições, organizações políticas e movimentos sociais, pois ela impulsiona mudanças não quantificáveis relacionadas aos direitos e à ação política das mulheres, e abre espaço para o desenvolvimento de novas demandas. ${ }^{67}$

O temor do essencialismo não deve impedir a sugestão de projetos que possam contribuir para melhorar a vida das mulheres e de outros grupos desfavorecidos. Fraser ${ }^{68}$ argumenta que as feministas precisam fazer afirmações normativas e oferecer alternativas emancipatórias. Para o projeto feminista ir além dos círculos feministas acadêmicos, se seu objetivo é maior do que somente desestabilizar as certezas políticas, as feministas precisam fazer afirmações em nome das mulheres, mesmo que provisoriamente, e tentar 
${ }^{69}$ Kathleen JONES, 1993, p. 16.

70 Gayatri SPIVAK, 1997. apontar sugestões para melhorar a situação de igualdade social e política delas. Apesar de a afirmação da identidade não dever se tornar uma meta em si, a afirmação estratégica da identidade continua necessária para o desenvolvimento de qualquer movimento político, mesmo daqueles abertos às coalizões. ${ }^{69} \mathrm{O}$ receio do essencialismo não pode, portanto, frear a luta pela igualdade de gênero, racial ou étnica, ou impedir afirmações sobre as desigualdades existentes entre mulheres e homens, negros e brancos, e entre minorias e maiorias étnicas.

Gayatri Spivak $^{70}$ introduz o conceito de essencialismo estratégico (um conceito do qual mais tarde ela se distancia, segundo ela, por seu uso indevido) para afirmar que às vezes é necessário que determinados grupos sociais simplifiquem a representação de suas identidades, essencializando-as, apesar de suas diferenças internas, para ganharem espaço político e atingirem seus objetivos. Spivak é contra o essencialismo na medida em que para ela as palavras assumem seus significados por meio do uso e de poderes discursivos, e o essencialismo pressupõe a unidade do sujeito e o significado essencial de termos específicos. O essencialismo, segundo a autora, é uma arapuca e não garante uma solução duradoura para a exclusão e a exploração. Por outro lado, ela afirma a impossibilidade de sermos totalmente não essencialistas. A estratégia é diferente da teoria, não é geral, mas direcionada e particular a uma situação. Assim, embora Spivak rejeite o essencialismo, ela reconhece a importância de sua utilização de forma estratégica.

O projeto de representação especial de grupo parece não poder escapar ao dilema da igualdade e da diferença. A afirmação política da diferença implica a construção de novos universalismos que reificam as diferenças entre os grupos e no interior deles. Se, por um lado, a construção do sujeito parece ser inevitável para projetos que almejem destacar os diferentes tipos de subordinação de grupo, propondo políticas para lidar com essas desigualdades, por outro lado, a essencialização das diferenças pode ter consequências tão danosas quanto a sua negação, na medida em que congela identidades que se pretendem mutáveis. Não é vantajoso para as mulheres, por exemplo, que o cuidado dos filhos permaneça como responsabilidade das mães ou que as mulheres sejam caracterizadas como naturalmente "cuidadoras" e empáticas, enquanto os homens como naturalmente autointeressados. Ao contrário, o projeto por igualdade de gênero pressupõe a desnaturalização das tarefas e dos atributos tradicionalmente assumidos como sendo femininos ou masculinos e, portanto, acolhe a desconstrução das diferenças. 
Mas, por outro lado, construir a equidade de gênero implica levar em conta as diferenças que dificultam a participação social, econômica, cultural e política das mulheres em igualdade de condições com os homens. Em nome da desconstrução das diferenças, o projeto feminista não pode negar as desigualdades existentes, abrindo mão de propor iniciativas que ajudem a mudar a condição social e a qualidade de vida das mulheres. Como encarar esse dilema da igualdade e da diferença tem sido um dos focos principais do debate feminista das últimas décadas.

Uma saída aparentemente possível é um essencialismo estratégico, em que as diferenças sejam enunciadas estrategicamente com vistas a atingir objetivos políticos, sem que com isso se tornem fixas. Elas seriam resultantes de momentos e espaços específicos em constantes processos de mudança. $O$ essencialismo fixa identidades que são mutáveis e, como discurso da diferença, contribui para perpetuar as relações de poder e subordinação. O essencialismo estratégico pode servir de fonte de mudança, na medida em que reconhece que as diferenças, apesar de plurais e mutáveis, precisam ser afirmadas para fins políicos.

As reflexões apresentadas neste artigo fazem parte de um debate controverso sobre representação política, representação de grupos e cotas. A sugestão de que membros de grupos discriminados melhor representariam os seus interesses e as suas perspectivas pode ser contestada a partir de diferentes posições teóricas de força normativa. No entanto, é cada vez mais consensual que há algo de errado quando um espaço de tomada de decisão é composto majoritariamente de membros de elites econômicas, raciais, étnicas e de gênero. Apesar das controvérsias presentes no debate sobre representação especial de grupos, a tendência crescente é considerar que os espaços político-decisórios são mais representativos e responsivos quanto mais efetivos forem em incorporar no seu processo deliberativo membros de diferentes grupos sociais. Com todos os problemas inerentes a esse projeto, ele representa um dos mais eficazes para incluir diferentes perspectivas no processo político-decisório, potencializando a construção de políticas que melhor atendam às necessidades e aos interesses de grupos diferentemente posicionados na estrutura social.

\section{Referências}

ARAÚJO, Clara. "As cotas por sexo para a competição legislativa: o caso brasileiro em comparação com experiências internacionais". Dados, v. 44, n. 1, p. 155194, 2001a. 
. "Potencialidades e limites da política de cotas no Brasil". Revista Estudos Feministas, v. 9, n. 1, p. 231-52, $2001 b$.

AVELAR, Lúcia. Mulheres na elite política brasileira: canais de acesso ao poder. São Paulo: Fundação Konrad Adenauer, 1996.

BOYLE, Christine. "Home Rule for Women: Power Sharing Between Men and Women." Dalhousie Law Journal, v. 7, n. 3, p. 790-809, 1983.

BUTLER, Judith. "Contingent Foundations." In: BENHABIB, Seyla et al. (Org.). Feminist Contentions: A Philosophical Exchange. Nova York: Routledge, 1995. p. 35-38.

DUERST-LAHTI, Georgia; VERSTEGEN, Dayna. "Making Something of Absence: The Year of the Woman and Women's Representation." In: DUERST-LAHTI, Georgia; KELLY, Rita Mae (Ed.). Gender Power Leadership and Governance. Michigan: University of Michigan Press, 1995. p. 213-238.

EISENSTEIN, Zillah R. The Radical Future of Liberal Feminism. Londres: Longman, 1981.

FRASER, Nancy. "False Antithesis: A Response to Sheila Benhabib and Judith Butler." In: BENHABIB, Sheyla et al. (Ed.). Feminist Contentions. Londres: Routledge, 1995. p. 59-74.

. Justice Interruptus. Londres: Routledge, 1997.

HABERMAS, Jurgen. Legitimation Crisis. Londres: Heinemann, 1976.

JONES, Kathleen. Compassionate Authority: Democracy and the Representation of Women. London/Nova York: Routledge, 1993.

LACLAU, Ernesto; MOUFFE, Chantal. Hegemony and Socialist Strategy: Towards a Radical Democratic Politics. 2. ed. Londres: Verso, 2001.

LISTER, Ruth. The Exclusive Society: Citizenship and the Poor. Londres: Poverty Action Group, 1990. 1997.

. Citizenship: Feminist Perspectives. Londres: Macmillan,

MANSBRIDGE, Jane. "Should Blacks represent Blacks and Women represent Women? A Contingent 'Yes.' Journal of Politics, v. 61, n. 3, p. 628-657, 1999.

MIGUEL, Luís Felipe. "Teoria política feminista e liberalismo: o caso das cotas de representação". Revista Brasileira de Ciências Sociais, São Paulo, n. 44, p. 91-102, 2000.

. "Política de interesses, política do desvelo: representação política e 'singularidade feminina'". Revista Estudos Feministas, Florianópolis, v. 9, n. 1, p. 253-267, 2001.

MOUFFE, Chantal. The Return of the Political. Londres/Nova York: Verso, 1993.

. "Deliberative Democracy or Agonistic Pluralism?" Social Research, v. 66, n. 3, p. 745-758, 1999. 
NASH, Kate. "Beyond Liberalism? Feminist Theories of Democracy." In: RANDALL, Vicky; WAYLEN, Georgina (Ed.). Gender, Politics and the State. Londres: Routledge, 1998. p. 45-57.

NORRIS, Pippa; LOVENDUSKI, Joni. Political Recruitment. Cambridge: Cambridge University Press, 1995.

OKIN, Susan Moller. Gender, Justice and the Family. Nova York: Basic Books, 1989.

. "Gender, the Public and the Private." In: HELD, David (Org.). Political Theory Today. Stanford: Stanford University Press, 1991. p. 67-90.

PATEMAN, Carole. The Sexual Contract. Cambridge: Polity Press, 1988.

The Disorder of Women. Stanford: Stanford University Press, 1989.

PHILLIPS, Anne. Engendering Democracy. Cambridge: Polity Press, 1991. 993.

Democracy and Difference. Cambridge: Polity Press,

The Politics of Presence. Oxford: Clarendon Press, 1995.

Which Equalities Matter? Cambridge: Polity Press, 1999.

PITKIN, Hanna. The Concept of Representation. Londres: University of California Press, 1967.

RAI, Shirin. "Democratic Institutions, Political Representation and Women's Empowerment: The Quota Debate in India." Democratization, v. 6, n. 3, p. 86-99, 1999.

RANDALL, Vicky. "Legislative Gender Quotas and Indian Exceptionalism: The Travails of the Women's Reservation Bill." Comparative Politics, v. 39, n. 1, p. 63-82, 2006.

SACCHET, Teresa. "Beyond Numbers: The Impact of Gender Quotas in Latin America." International Feminist Journal of Politics, Londres: Routledge, v. 10, n. 3, p. 369-386, 2008.

SACCHET, Teresa; SPECK Bruno. "Financiamento eleitoral e representação política: o peso do dinheiro e o desequilíbrio de gênero nas esferas legislativas". In: ANPOCS, 2010, Caxambu.

SAPIRO, Virginia. "When are Interests Interesting." In: PHILLIPS, Anne (Org.). Feminism and Politics. Oxford: Oxford University Press, 1998. p. 165-187.

SAWER, Marian. "Feminism, Representation and Impartiality." In: POLITICAL STUDIES ASSOCIATION CONFERENCE, $10 \mathrm{abr}$. 2000, Londres.

SCOT, Joan Wallach. Gender and the Politics of History. Nova York: Columbia University Press, 1988.

SPIVAK, Gayatri. "In a Word." In: NICHOLSON, Linda J. (Org.). The Second Wave: A Reader in Feminist Theory. Londres: Routledge, 1997. p. 356-378. 
TAYLOR, Charles. "The Politics of Recognition." In: TAYLOR, Charles et al. (Org.). Multiculturalism: Examining The Politics of Recognition. Princeton: Princeton University Press, 1994. p. 25-74.

TOURAINE, Alain. The Voice and the Eye: An Analysis of Social Movements. Cambridge: Cambridge University Press, 1981.

VINCENT, Louise. "Pessimisms about Presence: A View from South Africa's First Two Democratic Parliaments." In: POLITICAL STUDIES ASSOCIATION, 2002, Londres.

VOGEL, Ursula. "Is Citizenship Gender-Specific?" In: VOGEL, Ursula; MORAN, Michael (Ed.). The Frontiers of Citizenship. Londres: Macmillan, 1991. p. 58-85.

WALBY, Sylvia. "Is Citizenship Gendered?" Sociology, v. 28, n. 2, p. 379-395, 1994.

YOUNG, Iris Marion. "Humanism, Gynocentrism and Feminist Politics." Women's Studies International Forum, v. 8, p. 173-183, 1985. . Justice and the Politics of Difference. Princeton: Princeton University Press, 1990. . Inclusion and Democracy. Nova York: Oxford University Press, 2000.

[Recebido em 23 de novembro de 2010 e aceito para publicação em 15 de dezembro de 2011]

\section{Political Representation, Group Representation and Quotas Policy: Feminist Views and Debates}

Abstract: This article focus on the debate of political representation, especial group representation, and the policy of quotas with the purpose of highlighting their main and most contentious arguments, exploring their inconsistencies, problematizing and establishing a dialogue between them. It will be considered to what extent the argument for the inclusion of non-hegemonic group members in the political decision making process, through means such as quotas, may be justified from a normative standpoint. Given the contentious character of the concept of political representation and of the notion of group identity and interest, to what extent could this demand be justified? This discussion will be carried out through a critical analysis on the meaning of political representation, the notion of group rights, interests, identities and perspectives, and the main arguments for and against quotas. The article will be centered on the debate about the political representation of women, establishing thus a close dialogue with and between feminist perspectives.

Key Words: Political Representation; Group Representation; Quotas; Democracy; Women; Gender. 